\title{
TRADE OFF BANK ISLAM INDONESIA: MORALITY ATAU BUSINESS ENTITY DALAM PENGELOLAAN LIKUIDITAS
}

\author{
Yenni Kornitasari ${ }^{1}$ \\ ${ }^{1}$ Fakultas Ekonomi dan Bisnis, Universitas Brawijaya \\ Email: yenny_kornitasari@yahoo.com
}

\begin{abstract}
The purpose of this paper is to examine related to Islamic banking operations in Indonesia, which focused on issues of liquidity management is carried out by Islamic banks in Indonesia. This study, using a qualitative approach to the analysis unit of interviews and observations are supported by the literature to illustrate a systematic, factual and accurate information related to the phenomenon that is being written with the results of the study in the form of a conceptual study. Based on the results of the study that the behavior of Islamic banking liquidity management with institutional approach faces problems of a trade off between the existence of Islamic banking as a business entity, and the presence of Islamic banks principled terms would value. So that the development of Islamic banks currently tend to be "permissive" by some of the things that are in support of the principles of Islamic banking in order to grow more massive. This problem appears more dilantarbelakangi by the presence of Islamic banking in Indonesia is growing in the mechanism of the dual banking system, in which Islamic banking goes linearly with conventional banking, including in the face of business competition. It's a bit much cause "injustice" for Islamic banking itself, considering the existence of conventional banking is already far ahead of the growing Islamic banking.
\end{abstract}

Keywords: Bank Islam, Dual Banking, Trade-off

JEL Classification: Z12, G21

\section{PENDAHULUAN}

Dalam dua dekade terakhir, setidaknya telah terjadi dua krisis keuangan yang cukup besar terjadi, yaitu krisis keuangan Asia Timur 1997 dan krisis keuangan global 2008. Di mana fenomena terjadinya krisis keuangan tersebut dapat dikaitkan dengan beberapa hal penting, pertama adalah kegagalan di pasar keu-angan, kedua, situasi di mana institusi atau lembaga keuangan kehilangan sebagian be-sar assetnya, ketiga, kepanikan perbankan, default kredit, dan resesi dan keempat runtuhnya bursa efek dan nilai mata uang yang terus jatuh (Mishkin, 2004).

Berawal dari permasalahan krisis moneter yang terjadi pada tahun 1997 yang ditandai dengan jatuhnya mata uang Baht (Thailand) yang disusul dengan penurunan nilai mata uang negara Asia Timur lainnya termasuk nilai rupiah Indonesia. Penurunan nilai rupiah ini menyebabkan Bank Indonesia melakukan kebijakan pengetatan likuiditas dengan menaikkan suku bunga Sertifikat Bank Indonesia (SBI) dari 6\% menjadi 14\% (Bank Indonesia, 2013).

Hal ini mengakibatkan bank-bank umum meminta bantuan Bank Indonesia se-laku lender of the last resort untuk memberikan bantuan dana talangan kepada bank dalam situasi darurat yang dikenal dengan Bantuan Likuiditas Bank Indonesia. Karena sesehat apa pun sebuah bank, apa-bila uang dari masyarakat ditarik serentak tentu bank tidak akan sanggup 
meme-nuhinya sehingga timbullah permasalahan likuiditas secara nasional. Karena dengan adanya permasalahan ini dapat mengaki-batkan permasalahan sistemik. Hal ini di-buktikan dengan ditutupnya 15 bank umum saat terjadi krisis pada tahun 1997 karena terjadinya permasalahan likuiditas di per-bankan.

Selanjutnya, belum selesai dampak permasalahan likuiditas yang terjadi di pada tahun 1997 , pada pertengan tahun 2007 dunia di kagetkan dengan negara Amerika Serikat yang dilanda krisis subprime mort-gage dan memuncak pada September 2008, yang ditandai dengan pengumuman ke-bangkrutan beberapa lembaga keuangan. Awal mula krisis tersebut terjadi pada peri-ode 2000-2001, ketika saham perusahaan dotcom di Amerika Serikat kolaps, se-hingga perusahaan-perusahaan yang me-nerbitkan saham tersebut tidak mampu membayar pinjaman ke bank sehingga me-nyebabkan bank mengalamai permasalahan likuiditas dan terjadinya gagal bayar yang berakibat sistemik pada lembaga keuangan maupun kondisi perekonomian(Haz, 2006).

Dengan melihat fenomena krisis keuangan yang terjadi di perekonomian konvensional tersebut telah mendorong perkembangan keuangan Islam sebagai alternatif bagi masyarakat dalam meminimalisir terjadinya krisis keuangan. Hal ini dibuktikan dengan perkembangan industri perbankan Islam di dunia tiga dekade belakangan ini mengalami perkembangan yang cukup baik dengan pertumbuhan aset sekitar \$500 miliar sampai dengan $\$ 1$ tri-liun dengan rata-rata pertumbuhan sekitar 10\%-20\% per tahunnya (Ismal, 2011).

Perkembangan tersebut juga diikuti oleh industri perbankan Islam yang ada di Indonesia sebagai salah satu negara yang menggunakan sistem Islam dalam operasi perbankannya dengan kerangka dual banking system. Di mana perkembangan bank Islam cukup impresif, dengan rata-rata pertumbuhan aset lebih dari $65 \%$ per-tahun dalam lima tahun terakhir ini. Hal ini bisa dilihat pada Grafik 1 terkait dengan perkembangan aset yang ada diperbankan Islam.

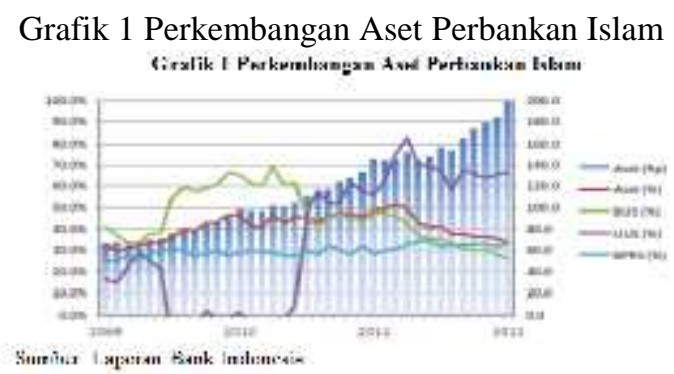

Sumber: Laporan Bank Indonesia, 2013

Pertumbuhan aset perbankan Islam yang terus mengalami peningkatan tersebut juga diikuti dengan pelaksanaan interme-diasi dana pihak ketiga yang dihimpun mencapai Rp150,5 triliun, ke berbagai segmen pembiayaan secara optimal. Hal ini tercermin dari besarnya pembiayaan yang mencapai Rp151,1 triliun yang mendorong kenaikan financing to deposit ratio per-bankan Islam, diantaranya dari $86,7 \%$ pada 2011 menjadi $95,4 \%$ pada akhir periode la-poran 2012. maka diharapkan peran indus-tri perbankan Islam dalam mendukung perekonomian nasional akan semakin signifikan (Bank Indonesia, 2013).

Hal ini menunjukan bahwa perbanan Islam harus melaksanakan fungsi inter-mediasi perbankan yang baik dengan me-lakukan pengelolaan likuiditas yang baik juga. Di mana likuiditas ini merupakan pe-nilaian dari kemampuan bank untuk me-menuhi kewajibannya, terutama kewajiban jangka pendeknya. Secara lebih terperinci, likuiditas adalah suatu kemampuan bank untuk memenuhi kewajibannya meliputi kemampuan untuk menjalankan kegiatan operasional bank sehari - hari, mengatasi kebutuhan dana yang mendesak dari nasa-bah, memuaskan permintaan nasabah akan pinjaman dan memberikan suatu kele-luasaan bagi masyarakat dalam meraih ke-sempatan 
investasi yang menarik dan menguntungkan (Anton, 2005).

Pada dasarnya bank Islam akan sulit mengalami permasalahan likuiditas dikarenakan ketika bank Islam mengalami kelebihan likuiditas karena dana pihak ketiga (DPK) masyarakat yang terhimpun di perbankan Islam yang secara otomatis sebenarnya akan mengalir ke sektor riil melalui instrumen pembiayaan Islam yang real sec-tor based. Akan tetapi pada pratiknya bank Islam sebagai lembaga intermediasi terka-dang mengalami kekurangan atau kelebihan dana atau mengalami permasalahan likuiditas. Hal ini antara lain disebabkan oleh perbedaan waktu (time lag) antara penerimaan dan penanaman dana atau mismatch di mana dana yang diterima tidak bisa langsung dapat digunakan dalam ben-tuk pembiayaan. Hal ini bisa dilihat dari perkembangan DPK maupun PYD pada Tabel 1.2 berikut ini;

Tahell Perkemhangan IIPK dan PYD Pertarkan lalam ti lndoaeria

\begin{tabular}{|c|c|c|c|c|c|c|c|c|}
\hline Iodilator & 2005 & 2016 & 2007 & 2209 & 2009 & 2010 & 2011 & 2012 \\
\hline$\overline{D P K^{*}}$ & $\omega_{252}$ & 21.91 & 280 & 3522 & 3922 & 13510 & 1130 & I1KSit \\
\hline FYT' & 1:68s & 21:6i: & 28837 & $304 ; 3$ & tid? & $7.01 \%$ & |1163i! & $165 i 2$ \\
\hline $\begin{array}{l}\text { Gap DFK } \\
\text { dan PYD }\end{array}$ & 245 & 13) & $-12 \pi$ & 11067 & $50+9$ & 748 & $1217 \%$ & 19339 \\
\hline
\end{tabular}

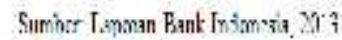

* dala milar rapab.

Perkembangan perbankan Islam dari peningkatan Dana Pihak Ketiga (DPK) bank Islam dari tahun ke tahun yang berbanding lurus dengan Pembiayaan Yang Diberikan (PYD) yang hampir berjalan seiring. Walaupun hal ini dapat dikatakan bahwa kelebihan likuiditas dari bank Islam dapat tersalurkan dengan baik, namun tidak menutup kemungkinan kelebihan likuiditas yang tidak produktif ini terjadi di masa datang. Kelebihan likuiditas ini berarti terdapat dana yang idle. Dana idle yang dimaksud disini adalah dana "tidak terpakai" atau tidak digunakan untuk keperluan tertentu yang mendesak. Jika bank Islam tidak dapat mengelolanya de-ngan segera maka bank akan mengeluarkan cost yang tentu akan merugikan bank itu sendiri. Selain itu, Bank Indonesia melihat bank tersebut tidak produktif dalam pengelolaan dana, secara otomatis mem-buat bank tersebut dapat berpredikat buruk dari Bank Indonesia.

Selanjutnya, ketidakseimbangan antara penyerapan dana pihak ketiga dan penyaluran pembiayaan jelas bukan masalah yang ringan bagi perbankan Islam. Karena perbankan Islam menganut sistem bagi hasil, maka hal itu merupakan salah satu beban yang ditangggung pihak bank yang juga otomatis akhirnya menjadi beban pihak deposan juga. Artinya imbal hasil yang diperoleh deposan bank Islam cenderung mengecil. Ketidakseimbangan ini merupakan permasalahan likuiditas yang serius yang dihadapi bank Islam, jika tidak segera diatasi dapat mengakibatkan kegagalan bank tersebut. Karena risiko likuiditas merupakan salah satu risiko terpenting yang harus dikelola dengan hati-hati oleh semua perbankan mengingat bahwa bank merupakan salah satu lembaga kepercayaan masyarakat yang mengemban fungsi intermediasi (Anto, 2010). Oleh karena itu, tulisan ini ingin menelaah terkait dengan perilaku perbankan Islam dalam pengelolaan likuiditas dengan meng-gunakan pendekatan kelembagaan.

\section{Perumusan Masalah}

Pratiknya perbankan termasuk Bank Islam yang berfungsi sebagai lembaga intermediasi terkadang masih mengalami kekurangan ataupun kelebihan dana sehingga akan menimbulkan permasalahan likuiditas. Hal ini disebabkan antara lain oleh perbedaan waktu (time lag) antara penerimaan dan penanaman dana atau mismatch di mana dana yang diterima tidak bisa lang-sung dapat digunakan dalam bentuk pem-biayaan.

Sehingga pengelolaan likuiditas dan fungsi intermediasi perbankan adalah hal yang menarik untuk dibahas dalam dunia perbankan saat ini. Hal ini penting mengingat bank merupakan salah satu lembaga yang mempunyai peran penting 
dalam menjaga kestabilan keuangan nasional. Oleh karena itu, tulisan ini ingin menelaah terkait dengan perilaku perbankan Islam yang terbatas pada aktifitas pengelolaan li-kuiditas dengan menggunakan pendekatan kelembagaan

\section{TINJAUAN PUSTAKA DAN HIPO-TESIS}

Dual Banking System : Persaingan Besar yang Dihadapi Bank Islam

Sistem perbankan nasional Indonesia yang saat ini sejak diberlakukannya Undang-undang No 10 Tahun 1998 tentang perubahan atas Undang-undang No $7 \mathrm{Ta}$ hun 1992, berisikan bahwa perbankan nasional Indonesia telah berkembang dengan menggunakan kerangka dual banking system di mana dual banking system yang dimaksud adalah bahwa selain terdapat perbankan konvensional yang telah lama berkembang, juga tumbuh secara berdampingan sistem perbankan Islam yang sesuai dengan prinsip-prinsip Islam. Pengembangan sistem perbankan Islam di Indonesia dengan kerangka dual banking system ini dilakukan oleh Arsitektur Perbankan Indonesia (API), untuk menghadirkan alternatif jasa perbankan yang semakin lengkap kepa-da masyarakat Indonesia. Kehadiran bank Islam di tengah-tengah perbankan konven-sional di sini adalah untuk menawarkan sis-tem perbankan alternatif bagi umat Islam, yang selama ini menikmati pelayanan per-bankan dengan sistem bunga (riba).

Strategi ini dilakukan berdasarkan pengalaman sewaktu krisis yang diketahui bank yang beroperasi berdasarkan prinsip Islam dapat bertahan di tengah gejolak nilai tukar dan tingkat suku bunga yang tinggi. Hal ini didukung oleh karakteristik kegiatan usaha bank Islam yang melarang bunga bank (riba) dan melarang transaksi keu-angan yang bersifat spekulatif. Keberadaan dua sistem perbankan yang berkembang secara paralel dan yang mempunyai hubu-ngan keuangan terbatas satu sama lain diha-rapkan akan dapat menciptakan diversi-fikasi risiko yang pada gilirannya akan me-ngurangi masalah systemic risk pada saat terjadi krisis keuangan.

Penerapan dual banking system ini dalam perbankan nasional, membuat timbulnya persaingan antar bank Islam, dan an-tar bank Islam dengan bank konvensional. Persaingan perbankan tersebut tidak terlepas dari segmentasi yang ada di pasar perbankan di Indonesia (Karim, 2003). Seg-mentasi pasar tersebut dibagi menjadi 3 segmen, yaitu segmen conventional, seg-men floating mass dan semen shariah loya-list. Segmentasi ini berlaku baik untuk pa-sar pembiayaan maupun pasar pendaanaan.

Gambar 1.

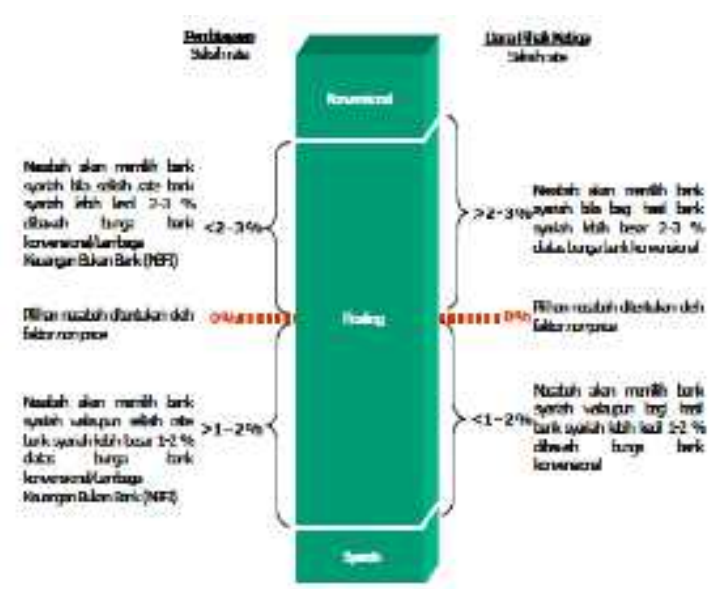

Dari segi segmentasi pasar pembiayaan, ketiga segmen ini terletak pada pandangannya terhadap biaya yang harus dibayar oleh nasabah suatu bank (pasar pembiayaan) atau penghasilan yang diterima (pasar pendanaan). Segmen konvensional akan memilih bunga karena bunga mencerminkan cost yang menguntungkan dari segi pembiayaan atau return yang menguntungkan dari segi pendanaan.

Berdasarkan gambar 1 untuk segmen shariah loyalist akan memilih Bank Islam, walaupun selisih rate Bank Islam berada 1-2 \% di atas bunga bank konvensional/Lembaga Keuangan Bukan Bank (LKBB) dari segi pembiayaan, dan 1-2\% 
lebih rendah dari segi pendanaan. Sebaliknya, segmen floating mass akan cenderung memilih biaya yang paling rendah atau $r e-$ turn yang paling tinggi. Pemilihan bank Islam akan terjadi apabila selisih rate bank Is-lam lebih kecil atau lebih besar 2-3\% dari bank konvensional atau Lembaga Keua-ngan Bukan Bank.

Dari segi market size, segmen terbesar justru terdapat pada segmen floating mass. Sebaliknya segmen terkecil terdapat pada segmen shariah loyalist. Menurut esti-masi KARIM Business Consulting (2003), di samping market size yang sangat besar da-ri segmen floating mass, sesuai nama-nya, segmen ini mencerminkan suatu seg-men yang memiliki perilaku yang dapat bergerak ke posisi memilih produk-produk bank konvensional atau memilih produk bank Islam. Akibatnya, suatu bank yang menyediakan jasa bank konvensional dapat kehilangan nasabah bila tidak mampu menyediakan jasa bank Islam.

Segmen shariah loyalist, di sisi lain, mencerminkan suatu segmen yang anti terhadap pelayanan bank konvensional. Sikap ini disebabkan pandangan bahwa bunga sa-ma dengan riba (haram atau terlarang). Akibatnya, bank konvensional akan sulit mempenetrasi segmen ini. Dalam realitanya, bank-bank Islam yang merupakan bagian dari dual banking systems (merupakan Unit Usaha Islam dalam suatu bank konvensional) juga akan mengalami kesulitan mempenetrasi segmen ini karena pandangan segmen ini yang cenderung mencari return dari simpanannya yang "benar benar halal". Segmen ini tampaknya lebih mudah menjadi target pasar dari bank-bank Islam yang berdiri sendiri seperti Bank Muamalat Indonesia dan Bank Islam Mandiri.

\section{Persaingan Perbankan Islam dan Perbankan Konvensional}

Perkembangan perbankan Islam di Indonesia setelah adanya perubahan UU Perbankan dengan UU No. 10/1998 mengalami pertumbuhan dan perkem- bangan yang cukup pesat. Perkembangan yang cukup pesat ini terutama sejak dikeluarkannya ketentuan Bank Indonesia yang memberi izin untuk pembukaan bank Islam (BUS) yang baru maupun pendiriaan Unit Usaha Islam (UUS). Dalam industri perbankan Islam, secara kuantitatif mau-pun kualitatif, Indonesia saat ini lebih baik. Jumlah bank umum Islam di Indonesia sampai dengan Juli 2010 berjumlah 10 unit yang terdiri dari Bank Muamalat Indonesia (BMI), Bank Islam Mandiri (BSM), Bank Islam Mega Indonesia, BRI Islam, Bank Bukopin Islam, Bank Panin Islam, Bank Victoria Islam, Bank BCA Islam, Bank Islam BNI dan Bank Jabar dan Banten, di-tambah lagi dengan perkembangan jumlah Unit Usaha Islam (UUS) dan jumlah BPR Islam. Belum lagi jumlah BMT yang juga ikut diperhitungkan. Dari sisi kuantitatif, prosentase jumlah perbankan Islam di Indonesia masih jauh kecil dibandingkan dengan jumlah perkembangan perbankan konvensional yang sudah lebih dulu berkembang (Laporan Direktorat Perbankan Islam Bank Indonesia, 2013).

Berikut ini hal yang membedakan antara perbankan konvensional dan perbankan Islam secara sistem maupun secara instrument yang dmiliki menyebabkan perbankan Islam maupun perbankan konvensional harus mampu bersaing dengan kinerja yang baik agar tetap bisa bertahan dan bersaing di dalam usaha perbankan nasional.

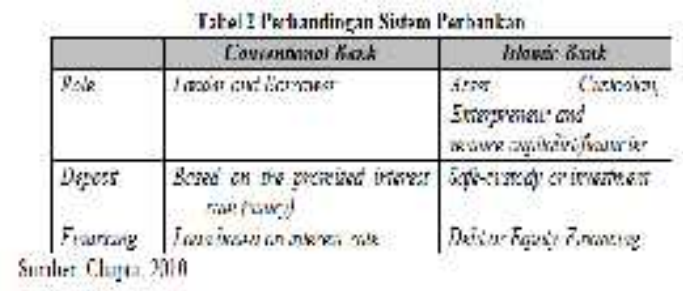

Perbedaan yang ditunjukan dalam Tabel 2 yang menyiratkan bahwa sistem perbankan Islam pada hakekatnya adalah suatu sistem yang berorientasi kepada kepemilikan (equity based system) seperti 
yang dinyatakan oleh Khan (1992) berikut ini:

The Islamic Banking System is an equity-based system in which depositors are treated as if they were shareholders of a bank. Conse-quently, deposits are not guaranteed the nominal value of their deposits or a predetermined rate of return on these deposits. If the bank makes profits then the shareholder (depositor) would be enti-tled to receive a certain proportion of these profits. On the other hand, if the bank incurs losses the depositor is expected to share in these as well, and would receive a negative rate of re-turn. Thus, from the depositor's pers-pective an Islamic Bank is in most res-pect identical to a mutual fund or investment trust.

Akan tetapi perbedaan yang paling mendasar dari kedua sistem perbankan tersebut adalah komponen pada bunga. Selain secara sistem kedua perbankan ini berbeda, jenis produk dan instrument moneter yang digunakanpun berbeda, seperti yang terlihat pada tabel dibawah ini:

Tabel 3 Jenis Produk dan Instrumen Moneter

\begin{tabular}{|c|c|c|}
\hline & Bank konvensional & Bank Islam \\
\hline Simpanan & $\begin{array}{ll}- & \text { Tabungan } \\
- & \text { Giro } \\
- & \text { Deposito } \\
& \text { Berjangka } \\
- & \text { Sertifikat } \\
& \text { Deposito (dapat } \\
\text { diperjual } \\
\text { belikan) }\end{array}$ & $\begin{array}{ll}\text { - } & \text { Tabungan } \\
\text { Wadi'ah atau } \\
\text { Mudharabah } \\
\text { - } \quad \text { Giro } \\
\text { Wadi'ah } \\
\text { - } \quad \text { Deposito } \\
\text { Mudharabah } \\
\text { - } \quad \text { Bentuk lain } \\
\text { berdasar } \\
\text { wadi'ah atau } \\
\text { mudharabah }\end{array}$ \\
\hline $\begin{array}{l}\text { Penyaluran } \\
\text { dana/pembiayaan }\end{array}$ & $\begin{array}{ll}- & \text { Kredit/Pinjaman } \\
- & \text { Sewa } \\
- & \text { Sewa-Beli } \\
- & \text { Pembiayaan } \\
& \text { Ekuitas } \\
- & \text { Anjak Piutang } \\
- & \text { Pinjaman } \\
& \text { Talangan } \\
- & \text { Pembiayaan lain }\end{array}$ & $\begin{array}{l}\text { Jual-beli } \\
\text { dengan } \\
\text { prinsip } \\
\text { muraba-hah, } \\
\text { istishna, } \\
\text { ijarah, salam } \\
\text { dan jual beli } \\
\text { lainnya } \\
\text { Pembiayaan } \\
\text { bagi hasil } \\
\text { dengan } \\
\text { prinsip } \\
\text { mudharabah, } \\
\text { musyarakah } \\
\text { dan bagi } \\
\text { hasil lainnya } \\
\text { Pembiayaan } \\
\text { lainnya }\end{array}$ \\
\hline
\end{tabular}

\begin{tabular}{|c|c|c|c|}
\hline & & & $\begin{array}{l}\text { dengan } \\
\text { prinsip } \\
\text { hiwalah, } \\
\text { rahn, qardh }\end{array}$ \\
\hline $\begin{array}{l}\text { Instrumen } \\
\text { Moneter } \\
\text { (kontrol } \\
\text { Jumlah Uang } \\
\quad \text { Beredar) }\end{array}$ & 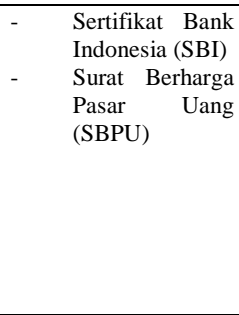 & - & $\begin{array}{l}\text { Sertifikat } \\
\text { Wadi'ah } \\
\text { Bank } \\
\text { Indonesia } \\
\text { (SBIS) } \\
\text { Surat } \\
\text { Berharga } \\
\text { Pasar Uang } \\
\text { Antar Bank } \\
\text { Syari'ah } \\
\text { (PUAS) }\end{array}$ \\
\hline
\end{tabular}

Sumber: Chapra, 2000

Tabel 3 pada prinsipnya perbedaan produk terlihat dari penggunaan sistem bunga pada produk bank konvensional dan sistem bagi hasil pada produk Bank Islam. Adapun jenis dan macam produk pada kedua jenis bank tersebut dapat dilihat pada Tabel 3. Dilihat dari jenis produk pem-biayaannya, terdapat perbedaan yang cukup mendasar antara bank konvensional dan Bank Islam. Dalam hal ini Bank Islam me-miliki ranah pembiayaan yang lebih luas, karena Bank Islam dapat dikatakan sebagai bank yang memiliki kemampuan gabungan dari kemampuan suatu commercial bank (bank umum) dan multifinance company (lembaga pembiayaan). Di sinilah letak keunikan dari suatu Bank Islam, yang se-mestinya dapat memberikan kekuatan dan kelebihan perbankan Islam. Kekuatan dan kelebihan itu semestinya dapat mendukung keberhasilan implementasi sistem perbankan baru tersebut yang harus mampu berkompetisi dengan sistem perbankan konvensional yang telah lama berkembang.

\section{Pengelolaan Likuiditas pada Perbankan: Bentuk Meminimalisir Risiko}

Pengelolaan likuiditas merupakan masalah yang sangat kompleks dalam kegiatan operasional suatu bank. Pemicu utama kebangkrutan bank, baik bank yang besar maupun bank yang kecil, bukanlah kare-na kegagalan pada pembiayaan yang me-nyebabkan kerugian, melainkan lebih kepa-da ketidakmampuan bank untuk melakukan pengelolaan likuiditas. Dalam terminologi keuangan dan perbankan 
banyak pengertian mengenai likuiditas. Antonio (2001), men-definisikan secara luas mengenai likuiditas sebagai suatu kemampuan untuk memenuhi dana (cash flow) dengan segera dan dengan biaya yang sesuai. Likuiditas penting bagi bank untuk menjalankan transaksi bisnis seharihari, mengatasi kebutuhan dana yang mendesak, memenuhi permintaan nasabah terhadap pinjaman, dan memberikan fleksibilitas dalam meraih kesempatan investasi yang menarik dan menguntungkan.

Dengan kata lain menurut definisi ter-sebut, suatu bank dikatakan likuid apabila dapat memenuhi kewajiban jangka pendek berupa penarikan uang dari penitip dana maupun dari para peminjam/debitur. Secara praktis, likuiditas bank dikaitkan dengan jumlah Dana Pihak Ketiga (DPK) pada waktu tertentu. Dalam hal ini, pemerintah Indonesia melalui Bank Indonesia mene-tapkan batas kewajiban minimum setiap bank untuk memelihara likuiditasnya uta-manya kewajiban kepada pihak ketiga.

Tujuan dari manajemen pengelolaan likuiditas di sini adalah untuk menjaga posi si likuiditas bank agar dapat memenuhi ke-tentuan bank sentral, mengelola alat-alat li-kuid agar selalu dapat memenuhi semua ke-butuhan cash flow, termasuk kebutuhan yang tidak diperkirakan, misalnya penari-kan tiba-tiba terhadap sejumlah giro atau deposito yang belum jatuh tempo, selain itu juga bank harus memperkecil adanya dana menganggur (idle funds) karena akan menjadi beban bank kalau terlalu banyak idle funds.

\section{Jenis dan Sumber Pengelolaan Likuidi-} tas pada Perbankan

Secara umum dalam dunia perbankan, pasti memiliki jenis dan sumber alat li-kuid dalam melakukan pengelolaan likui-ditasnya. Dapat dijelaskan bahwa jenis-je-nis alat likuid yang dimiliki oleh bank ter-diri dari:
1) Kas atau uang tunai (kertas dan logam) yang tersimpan dalam brangkas bank tersebut.

2) Saldo dana milik bank tersebut yang terdapat pada Bank Indonesia (Saldo Giro Bank Indonesia).

3) Tagihan atau deposito pada bank lain, termasuk bank koresponden.

4) Chek yang diterima, tetapi masih dalam proses penguangan pada Bank Indonesia dan bank Koresponden.

Dalam dunia perbankan, keempat jenis alat likuid tersebut sering disebut dengan "posisi uang" (money position) bank yang bersangkutan pada saat tertentu. Sedangkan menurut sumbernya, suatu dapat memperoleh alat-alat likuiditasnya yang diperlukan dari berbagai sumber di antaranya adalah:

1) Asset Bank yang akan Segera Jatuh Tempo

Kredit pinjaman kepada debitur atau cicilan pinjaman yang akan jatuh tempo dapat dianggap sebagai sumber lukiditas. Oleh karena itu, dalam kondisi kebijakan uang ketat, posisi likuiditas suatu bank akan rawan apabila keseluruhan portofolio kreditnya masuk katagori evergreen. Su-rat-surat berharga, instrumen pasar uang seperti Bank Acceptance, Serti-fikat Bank Indonesia, dan sertifikat deposito pada Bank lain yang akan segera jatuh tempo, dapat pula diang-gap sebagai sumber likuiditas dalam golongan ini.

2) Pasar Uang

Pasar uang adalah sumber likuiditas bank. Namun harus diakui bahwa tidak setiap bank mempunyai kemampuan untuk masuk ke pasar uang. Hal ini sangat dipengaruhi oleh besarnya suatu bank dan persepsi pasar uang atas Credit Worthiness bank tersebut. Dalam hal ini, para investor yang me-minjamkan uangnya ke bank akan melakukan analisa yang mendalam dan selektif terhadap tingkat dan konsistensi 
perkembangan penda-patan bank, kualitas asset, reputasi kesehatan manajemen, dan kekuatan modal bank.

3) Sindikasi Kredit

Pembentukan sindikasi kredit, selain bertujuan menyiasati Legal Lending Limit $(3 L)$ dan menyebarkan risiko, juga bertujuan untuk menjalin hubungan dengan bank-bank lain. Dengan demikian, ketika mengalami kesuli-tan lukiditas maka bank tersebut da-pat menyidikasi sebagian portofolio kreditnya kepada bank lain untuk mengatasi masalah tersebut.

4) Cadangan Likuiditas

Khususnya bank yang tidak dapat segera memperoleh dana pada saat diperlukan, bank tersebut biasanya membentuk cadangan likuiditas. $\mathrm{Ca}-$ dangan likuiditas biasanya dibentuk dengan cara memelihara saldo Kas dan Giro BI pada batas maksimal yang diperbolehkan.

5) Sumber Dana yang Sifatnya Last Resort

Salah satu sumber likuiditas yang sifatnya last resort, yang umum digunakan oleh kebanyakan bank adalah fasilitas line of credit dari bank lain. Bank yang menjalin hubungan kores-ponden dengan bank lain kemung-kinan dapat meminta fasilitas stand by line of credit dari bank kores-pondennya tersebut. Selain itu, Bank Indonesia bertindak sebagai leader of last resort untuk dunia perbankan atau lembaga keuangan bukan bank. Namun bantuan dana dari Bank Indo-nesia biasanya baru akan diman-faatkan oleh bank yang kesulitan li-kuiditas apabila sumber-sumber li-kuiditas lainnya tidak cukup untuk mengatasi kesulitan likuiditas yang dialaminya.

\section{Pilihan Intrumen Pengelolaan} Likuiditas Bank Islam di Indonesia: SBIS dan SIMA
Sertifikat Bank Indonesia Islam atau yang disingkat dengan SBIS merupakan salah satu instrumen operasi moneter Islam dilakukan melalui penjualan SBIS yang da-pat digunakan sebagai salah satu instrumen dalam pengelolaan likuiditas perbankan Is-lam. Di mana instrumen ini berdasarkan pada peraturan Bank Indonesia No.10/ 11 /PBI/2008 tanggal 31 Maret 2008. SBIS adalah surat berharga berdasarkan Prinsip Islam berjangka waktu pendek dalam mata uang rupiah yang diterbitkan oleh Bank Indonesia. SBIS yang diterbitkan oleh Bank Indonesia menggunakan akad Ju'alah. SBIS memiliki karakteristik sebagai berikut (i) satuan unit sebesar Rp.1.000.000,00 (satu juta rupiah); (ii) berjangka waktu paling kurang 1 (satu) bulan dan paling lama 12 (dua belas) bulan (iii) diterbitkan tanpa warkat (scripless); (iv) dapat diagunkan kepada Bank Indonesia; dan (v) tidak dapat diperdagangkan di pasar sekunder.

Berdasarkan fatwa Dewan Islam Nasional (DSN) dan Majelis Ulama Indonesia (MUI), SBIS juga dapat diterbitkan dengan menggunakan akad mudharabah, musyarakah, wadiah, qardh, dan wakalah. Mekanisme penerbitan SBIS dilakukan Bank Indonesia melalui mekanisme lelang dan menggunakan akad jua'alah. Pihak yang dapat ikut serta dalam lelang SBIS adalah Bank Umum Islam (BUS) atau Unit Usaha Islam (UUS) atau pialang yang bertindak untuk dan atas nama BUS/UUS; dan BUS atau UUS, baik sebagai peserta langsung maupun peserta tidak langsung, wajib memenuhi persyaratan Financing to Deposit Ratio (FDR) yang ditetapkan Bank Indonesia. Bank Indonesia memberikan imbalan atas SBIS yang diterbitkan.

Selanjutnya, Sertifikat IMA (SIMA) yang merupakan salah satu inovasi piranti keuangan di perbankan Islam yang dapat membantu pengembangan pasar uang antar bank. Dunia perbankan sering kali menggunakan fasilitas pasar uang dalam kegiatan operasionalnya, karena dalam 
keadaan ter-tentu terkadang bank dapat mengalami ke-lebihan ataupun kekurangan likuiditas da-lam jangka pendek yaitu kurang dari satu tahun. Bila terjadi kelebihan maka bank melakukan penempatan kelebihan likui-ditas, sehingga bank memperoleh keun-tungan. Dan sebaliknya bila bank me-ngalami kekurangan likuiditas maka bank memerlukan sarana untuk menutupi kekurangan likuiditas dalam rangka pembiayaan sehingga kegiatan operasional bank dapat berjalan dengan baik.

Salah satu piranti yang digunakan da-lam transaksi Pasar Uang antar Bank Islam (PUAS) adalah Sertifikat Investasi Mudha-rabah antar Bank Syari'ah (IMA) yang menggunaan prisip bagi hasil. Sertifikat ini digunakan sebagai sarana investasi bagi bank yang kelebihan dana untuk menda-patkan keuntungan, selain itu juga se-bagai sarana bagi bank syari'ah yang kekurangan dana untuk mendapatkan dana jangka pen-dek. Dalam PUAS instrumen ini akan menjadi instrumen yang diper-jualbelikan pada tahap pertama (first level scuritization), instrumen ini akan menjadi instrumen derivatif apabila disekuritisasi kembali (second level securitization) yang disepakati oleh para ulama untuk tidak boleh lagi diperjualbelikan (Karim, 2003).

Yang perlu menjadi catatan dalam pasar uang ini adalah bahwa dalam Islam yang diperbolehkan adalah penjualan bukti kepemilikan, bukan jual-beli sertifikat atas bukti kepemilikan. Karena sertifikat itu itu hanya mewakili harta yang dimiliki, namun karena bank Islam hanya berada pada sekuritas tahap pertama, maka ia tidak akan mengalami percepatan kuantitas moneter (monetary enchanment) di atas kuantitas di sektor riil.

\section{Prinsip-prinsip yang Perlu Diperhatikan dalam Pengelolaan Likuiditas}

Metode dan cara pengelolaan likuiditas yang diterapkan oleh masing-masing bank secara praktis akan saling berbeda, tergantung kepada metode manajemen dana yang diterapkan dan garis kebijakan dalam pengelolaan likuiditas. Namun demikian, terdapat kesamaan dalam prinsip-prinsip mendasar yang menjadi bingkai (frame work) pengelolaan likuiditas. Pengelolaan likuiditas harus dilakukan secara hati-hati dengan memperhatikan prinsip-prinsip yang ada. Oleh karena itu dalam penge-lolaan likuiditas bank perlu memperhatikan beberapa prinsip pengelolaan likuiditas yai-tu:

1) Bank harus memiliki sumber dana in-ti (core source of fund) yang sesuai dengan dengan sifat bank yang bersangkutan maupun pasar uang dan sumber dana yang ada dimasyarakat, serta yang cocok pula dengan meka-nisme pengumpulan dana yang berla-ku ditempat bank tersebut berada.

2) Bank harus mengelola sumber-sumber dana maupun penempatan dengan hati-hati. Oleh karena itu harus diper-hatikan komposisi sumber dana jatuh waktu berdasarkan jumlah masing-masing komposisi, tingkat suku bu-nga, faktor-faktor kesulitan dalam pengumpulan dana, produk-produk dana yang dimiliki dan sebagainya.

3) Bank harus memperhatikan different price for different customer di dalam penempatan dananya. Dan price (tingkat suku bunga) tersebut harus di atas tingkat suku bunga dana yang di-pakainya, atau dengan kata lain, ting-kat suku bunga atas penempatan dana tersebut harus bersifat floating.

4) Bank harus menaruh perhatian terhadap umur sumber dananya kapan akan jatuh tempo, jangan sampai terjadi maturity gap dengan penempatannya (placement). Oleh karena itu perlu diperhatikan prinsip pemenuhan kebutuhan dana yang sering menjadi acuan, yaitu: 
a. Kebutuhan dana jangka pendek harus dipenuhi dengan sumber dana jangka pendek.

b. Kebutuhan dana jangka panjang harus dipenuhi dengan sumber dana jangka panjang.

\section{METODE PENELITIAN}

Untuk mendukung penulisan ini, maka penulis menggunakan pendekatan pe-nelitian deskritif kualitatif dengan mela-kukan kegiatan wawancara dan observasi yang didukung dengan studi literatur yang mendalam, yakni dengan menggunakan pe-nulisan deskriptif dan data. Data pendeka-tan kualitatif diperoleh melalui prosedur yang menghasilkan datadata deskriptif, yang meliputi kata-kata tertulis atas objek penulisan yang sedang dilakukan yang di-dukung oleh studi literatur berdasarkan pe-ngalaman kajian pustaka, baik berupa data penulisan maupun angka yang dapat dipa-hami dengan baik.

Di samping itu, pendekatan kualitatif lebih peka dan dapat menyesuaikan diri de-ngan banyak penajaman pengaruh bersama serta pola-pola nilai yang dihadapi di lapangan (Moelong, 2002). Tujuan dari pe-nulisan deskriptif ini adalah untuk membuat deskripsi, gambaran atau lukisan secara sis-tematis, faktual dan akurat mengenai fakta-fakta, sifat serta hubungan antar fenomena yang diselidiki (Nazir, 2009).

\section{ANALISIS DATA DAN PEMBA- HASAN}

\section{Perkembangan Bank Islam di Indonesia: Pendekatan Kelembagaan}

Bank Islam mengalami perkembangan pesat dalam beberapa waktu terakhir di dunia. Gagalnya kinerja lembaga keuangan konvensional saat terjadinya krisis, menjadikan peralihan minat masyarakat pada bank Islam. Menurut Sudararajan dan Erico (2002) Bank Islam telah tumbuh secara ukuran dan secara signifikan telah bertambah besar di dunia. Secara struktur kelembagaan Bank Islam berbeda dengan bank konvensional. Sistem kontrak Bank Islam memiliki prinsip yang kuat dengan menghindari adanya unsur riba, gharar, dan maisir dalam hal ini Bank Islam tidak memakai unsur bunga.

Aris et.al (2013) menyatakan kontrak Bank Islam normalnya berbasis asset dengan menghilangkan unsur riba, gharar, dan maisir serta antara pemilik dana dan peminjam memiliki kontrak bagi hasil atas dana yang diinvestasikannya. Dalam perspektif teori, perbedaan mendasar Bank Islam dengan bank konvensional adalah kontrak yang menghilangkan unsur bunga (riba) karena dilarang oleh Islam (Chong dan Liu, 2009). Oleh karena itu perbedaan struktur kelembagaan yang paling tampak antara Bank Islam dengan bank konvensional adalah sistem kontrak yang menghapus adanya bunga yang dianggap sebagai riba.

Selain itu, operasional bank Islam lebih menekankan pada kemaslahatan masya-rakat. Dalam hal pelayanan, bank Islam le-bih menekankan pada keseimbangan antara kepentingan individu dan kepentingan ma-syarakat. Oleh sebab itu orientasi utama bank Islam adalah pelayanan pelanggan. Muhammad (2014) menyatakan bahwa prinsip utama Islam dalam mengelola harta lebih difokuskan pada keseimbangan antara kepentingan individu dan kelompok. Diper-kuat dengan pendapat Khan dan Bhatti (2008) bank Islam selalu berusaha menyei-mbangkan kepentingan individu dan ke-lompok untuk mengembangkan inovasi ser-ta berorientasi pada pelanggan dengan menyajikan produk yang kompetitif bagi klien mereka.

Menurut Iqbal (2012) Bank Islam pa-da umumnya membangun pengelolaan li-kuiditas yang baik dengan mengatur selu-ruh transaksi pada sektor riil. Penawaran kerjasama bank Islam mengikuti siklus bis-nis dengan membangun networking yang baik pada semua patner kerja atau pe-mangku kepentingan pada bank Islam. Dengan 
demikian bank Islam Faruq dan Za-heer (2015) dalam penelitiannya menemu-kan bahwa karakteristik Bank Islam menunjukkan adanya peran dengan membawa label agama, akibatnya dalam operasionalnya pergerakan pembiayaan Bank Islam banyak dialokasikan pada sektor riil.

Penyaluran dana yang dilakukan oleh Bank Islam dengan skema penghapusan tingkat bunga akan menghilangkan resiko fluktuasi tingkat bunga. Adanya perubahan pada tingkat bunga tidak berdampak pada kinerja penyaluran dana Bank Islam. Menurut Hachicha dan Amar (2015) tidak seperti bank konvensional, prinsip-prinsip yang diterapkan Bank Islam pada penya-luran dana memungkinkan untuk mendistribusikan resiko secara adil. Ditambah dengan pendapat Khan dan Bashar (2008) yang menyatakan bahwa prinsip pembagian risiko tersebut akan memastikan efisiensi perekonomian.

Namun yang terjadi di Indonesia, penyaluran besar Bank Islam justru tidak teralokasikan pada sektor-sektor primer seperti pertanian, pertambangan dan industri. Alokasi kredit sektoral Bank Islam banyak terfokus pada jasa dunia usaha dan kredit kategori lain-lain. Fenomena ini menunjukan bahwa pembiayaan yang dilakukan Bank Islam di Indonesia belum sepenuhnya terfokus pada sektor riil. Dorongan terha-dap sektor riil malah justru lebih kecil. Ma-sih perlu adanya desain kelembagaan pe-nyaluran dana yang lebih mengarah pada sektor riil. Sehingga teori bank Islam yang seharusnya memihak pada sektor riil dapat tercipta. Berikut tabel 4 yang menunjukan penyaluran kredit yang dilakukan oleh perbankan Islam pada sektor ekonomi

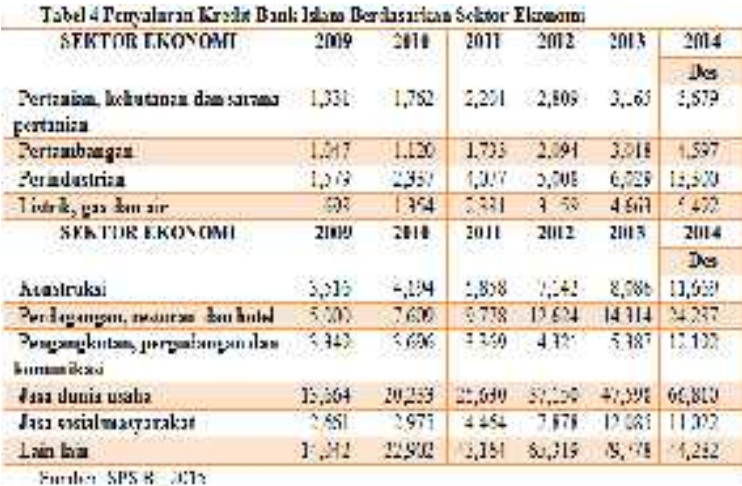

Selanjutnya jika dilihat berdasarkan akad, penyaluran mudharaba mendominasi alokasi pembiayaan yang dilakukan bank Islam. Hal ini semakin menunjukkan bahwa bank Islam di Indonesia belum sepenuhnya dalam mendorong sektor riil. Dibandingkan dengan alokasi pembiayaan mudharabah, jumlah alokasi pembiayaan dengan akad murabahah jauh lebih besar. Konsep kerjasama pada akad mudharabah menawarkan bagi hasil atas usaha yang dilakukan, sedangkan kontrak jual beli pada akad $m u$ rabahah menawarkan keuntungan yang tinggi pada bank. Penyaluran dengan akad murabaha memiliki proporsi yang besar dibanding dengan akad lainnya. Hal tersebut dapat dilihat pada gambar 3 berikut ini;

Menurut Sidiqqi (2008) penyaluran dana dengan tipe kontrak murabaha yang paling banyak digunakan oleh masyarakat karena akad murabahah digunakan untuk pembiayaan barang-barang konsumtif seperti kendaraan, rumah bagi rumah tangga dan bahan baku, mesin bagi industri atau perusahaan. Murabahah merupakan istilah dalam fiqih untuk transaksi jual beli ketika penjual menyebutkan secara spesifik biaya perolehan barang, termasuk biaya pencarian barang dan biaya-biaya lainnya yang dikeluarkan dalam memperoleh barang serta tingkat keuntungan yang diingin-kan (Ascarya, 2007). Menurut Kabir et.al (2015) pembagian risiko pada pembiayaan Bank Islam sangat terbatas. 
Gambar 3 Penyaluran Kredit Islam Berdasarkan Akad

$$
\begin{aligned}
& \text { Pembiayaan (Rp M) } \\
& \text { A.000.008 } \\
& \text { Akad Mudharabah } \text { Akad Musyarakah } \\
& \text { Akad Murabahah Akad Salam } \\
& \text { Akad Istishna } \quad \text { Akad ljarah }
\end{aligned}
$$

Sumber: SPS BI, 2015

Kondisi tersebut sangat disayangkan karena penerapan Profit and Loss Sharing (PLS) di Bank Islam Indonesia yang menjadi pembeda paling utama dengan perbankan konvensional masih belum bisa berjalan efektif. Dalam implementasinya bank Islam masih menggunakan produkproduk yang menyerupai bank konvensional dengan mengganti unsur bunga dengan unsur diskon dan biaya-biaya yang menyerupai bunga. Dengan demikian risiko yang ditanggung dalam PLS bank Islam sangat memungkinkan untuk sama dengan risiko yang dihadapi oleh bunga pada bank konvensional. Beck et. al (2013) menyatakan bahwa keuangan Islam yang bergantung pada gagasan risiko bagi hasil secara jelas membedakan sisi kelembagaan bank Islam dengan bank konvensional, namun saat ini dalam prakteknya ulama masih menggunakan produk-produk yang menyerupai produk bank konvensional dengan mengganti unsur bunga dengan bagi hasil dan lainnya.

\section{Trade Off Pilihan Instrumen Pengelolaan Likuiditas Perbankan Islam: SBIS, SI-MA, dan Fasilitas Diskonto}

Pengelolaan likuiditas merupakan sa-lah satu masalah yang sangat kompleks da-lam kegiatan operasional suatu bank. Pemi-cu utama kebangkrutan bank, baik bank yang besar atau bank yang kecil, bukanlah karena kerugian yang diderita bank tersebut, tetapi lebih kepada ketidakmam-puan suatu bank untuk melakukan penge-lolaan likuiditasnya. Tujuan dari mana-jemen pengelolaan likuiditas $\mathrm{d}$ isini adalah untuk menjaga posisi likuiditas bank agar selalu berada pada posisi yang telah diten-tukan oleh bank sentral, mengelola alat-alat likuid agar selalu dapat memenuhi semua kebutuhan cash flow, termasuk kebutuhan yang tidak diperkirakan, misalnya penarikan yang secara tiba-tiba terhadap sejumlah giro atau deposito yang belum jatuh tempo, selain itu juga bank harus memperkecil ada-nya dana menganggur (idle funds) karena akan menjadi beban bank kalau terlalu banyak idle funds.

Hal ini menyangkut masalah dana yang dihimpun oleh perbankan dari Dana Pihak Ketiga (DPK) yang sebagian besar si-fatnya adalah jangka pendek dan datangnya tidak terduga. Permasalahan likuiditas pasti dialami setiap harinya oleh pihak perban-kan, baik yang konvensional maupun Islam di mana salah satunya adalah posisi antara DPK dan PYD (Pembiayaan yang diberi-kan) yang setiap harinya tidak seimbang, yaitu lebih besar DPK yang masuk dari pa-da PYD yang disalurkan.

Pada Bank Islam tersebut sangat memperhatikan seakurat mungkin pengelo-laan dan kebutuhan likuiditas untuk jangka waktu tertentu, karena perkiraan kebutuhan likuiditas sebagian besar perbankan dipe-ngaruhi oleh perilaku penarikan nasabah yang tidak tentu dan jenis sumber dana yang dikelola oleh pihak perbankan terse-but. Permasalahan likuiditas di perbankan Islam tersebut jika tidak segera diatasi maka akan dapat menimbulkan permasalahan pada bank itu sendiri, salah satunya adalah timbulnya biaya untuk mengelola dana tersebut. Karena perbankan Islam menganut sistem bagi hasil, maka hal itu merupakan salah satu beban yang harus ditangggung pihak bank yang juga secara otomatis akhir-nya menjadi beban pihak deposan juga. Artinya imbal hasil yang diperoleh 
deposan Bank Islam cenderung mengecil. Hal ini sesuai dengan informasi yang disampaikan oleh informan Bapak Achmad (bukan nama sebenarnya) sebagai salah satu pegawai Bank Islam tersebut sebagai berikut:

“...begini mbak, untuk masalah pengelolaan likuiditas yang tiap harinya antara DPK dan PYD kita tidak seimbang harus segera dikelola dana tersebut, apalagi keseringan dana dari bank kami kelebihan, maka harus segera di-salurkan ke pihak lain, jangan sampai dana itu nganggur di bank, karena da-pat menimbulkan beban tersendiri, apalagi ini kita bank Islam yang harus melakukan bagi hasil dari dana yang diperoleh dari pihak nasabah".

Kenyataannya permasalahan likuiditas memang tidak bisa dihindari oleh semua perbankan, baik ketika bank itu kelebihan maupun kekurangan likuiditas pasti me-nimbulkan suatu permasalahan juga jika ti-dak segera diatasi. Sesuai dengan fasilitas yang tersedia di Bank Indonesia dalam mekanisme pengelolaan likuiditas pada bank Islam ada beberapa alternatif yang da-pat digunakan antara lain: Pertama, melalui Pasar Uang Antarbank Berdasarkan Prinsip Islam (PUAS), Kedua , fasilitas Sertifikat Bank Indonesia Islam (SBIS), dan ketiga Fasilitas Pembiayaan Jangka Pendek Bagi Bank Islam dari Bank Indonesia.

Dari ketiga alternatif media yang tersedia tersebut, satu alternatif dengan fasilitas pembiayaan jangka pendek bagi Bank Islam tersebut tidak digunakan (sangat dihindari) oleh perbankan Islam tersebut, hal ini sesuai dengan informasi yang disampaikan oleh informan bahwa:

“...ada mbak, diperbankan Islam untuk media pengelolaan likuiditasnya bisa menggunakan fasilitas SBIS, bisa pinjam meminjam antar bank, dan bisa minta bantuan ke Bank Indonesia langsung, tapi kita hampir tidak pernah menggunakan pinjaman dari BI".

Berdasarkan informasi tersebut, dapat dianalisa bahwa pada perbankan Islam tersebut tidak menggunakan fasilitas pembiayaan jangka pendek yang diberikan oleh Bank Indonesia. Hal ini sangat wajar kare-na terkait dengan penilaian Bank Indonesia terhadap kinerja dari perbankan Islam terse-but. Jika Bank Islam yang bersangkutan menggunakan fasilitas tersebut, maka Bank Indonesia dapat langsung menilai buruk da-ri kinerja perbankan Islam yang bersang-kutan. Oleh karena itu, fasilitas ini sangat dihindari oleh perbankan Islam, meskipun harus menggunakan fasilitas ini dengan kondisi yang terpaksa ketika dua alternatif yang lain sudah tidak dapat digunakan lagi dalam memberikan bantuan untuk pengelo-laan likuiditas.

Dari ketiga alternatif yang ada untuk melakukan pengelolaan likuiditas tersebut, pada bank Islam tersebut hanya mengguna-kan dua alternatif yaitu dengan menitipkan atau mengambil dana mereka yang ada di Bank Indonesia melalui instrument SBIS yang dimiliki oleh bank Islam di Bank Indonesia dan melalui transaksi Pasar Uang Antar Bank Islam (PUAS). Akan tetapi sering kali yang dilakukan oleh Bank Islam dalam pengelolaan likuiditasnya dengan menggunakan SBIS, karena dianggap yang paling aman dan memiliki risiko yang kecil dibandingkan dengan menyalurkan dana-nya ke PUAS. Hal ini sebagaimana disam-paikan oleh salah satu informan kepada peneliti bahwa:

“...ketika kelebihan likuiditas biasanya lebih aman kita ke SBIS mbak, ka-rena di Bank Islam kan tidak ada call money, dan keuntungnya di SBIS bisa diambil sewaktu-waktu ketika kita bu-tuh dan risikonya lebih kecil daripada harus ke PUAS, tapi 
meskipun demi-kian kita juga menyalurkan ke PUAS namun prosentasenya lebih kecil jika dibandingkan dengan SBIS, karena di PUAS biasanya risikonya lebih tinggi"

Kenyataannya, berdasarkan informasi tersebut di sini perbankan Islam dalam memilih media untuk melakukan pengelolaan likuiditasnya masih mempertimbangkan aspek keuntungan dan risiko yang akan dihadapi, sehingga ketika ada pilihan yang lebih menguntungkan dan risiko yang lebih kecil maka secara otomatis akan dipilih dan digunakan sebagai media dalam pengelo-laan dana likuiditasnya. Hal ini dapat dilihat dari dua pilihan alternatif yang digunakan oleh perbankan Islam tersebut untuk lebih mengutamakan penggunaan SBIS daripada PUAS, meskipun kedua alternatif tersebut samasama digunakan untuk melakukan pengelolaan likuiditasnya akan tetapi secara subtasi memiliki perbedaan yang cukup mendasar dari kedua pilihan terse-but.

Pada dasarnya sedikit perlu dianalisa ketika perbankan Islam tersebut lebih mengutamakan pemilihan pada fasilitas SBIS untuk pengelolaan likuiditasnya karena secara teknis operasional dalam pengelolaan likuiditas melalui SBIS menunjukkan seca-ra sederhana bahwa dalam operasional per-bankan Islam tersebut belum secara maksi-mal menjalakan salah satu prinsip yang sesuai dengan prinsip Islam yaitu harta yang seharusnya dapat berputar sehingga tidak boleh hanya berpusat pada segelintir orang dan Islam sangat tidak menyukai orang yang menimbun harta sehingga men-jadikannya tidak produktif, karena ketika dana tersebut dikelola melalui SBIS dana tersebut hanya diam di Bank Indonesia. Secara teoritis penerapan SBIS tersebut pada perbankan Islam ditujukan sebagai instrumen keuangan dengan prinsip Islam sebagai pengganti Sertifikat Bank Indonesia (SBI) karena masih mengguna kan sistem bunga berbasis riba berupa $B I$ rate.

Sebenarnya, ketika Bank Islam tersebut menggunakan SBIS dalam pengelolaan likuiditasnya juga menimbulkan per-masalahan tersendiri bagi perekonomian maupun bagi pihak perbankan Islam itu sendiri. Pertama bagi perekonomian karena ketika bank Islam secara umum menyimpan dananya pada SBIS dapat membebani Bank Indonesia karena harus membayar bonus kepada Bank Islam sebagai imbalan peni-tipan dana, padahal penumpukan dana perbankan Islam pada SBIS dapat menyebabkan "kelesuan" sektor riil karena dana yang seharusnya dialokasikan untuk pembi-ayaan, justru mengendap di SBIS yang ti-dak menyentuh sektor riil sama sekali. Me-lihat fakta di atas, sebenarnya penerapan SBIS tidak sesuai dengan konsep Ekonomi Islam yang sesungguhnya, dimana seharus-nya perputaran dana harus diiringi dengan pergerakan sektor riil, sedangkan pada SBIS tidak demikian.

Selain itu, kedua permasalahan yang timbul adalah ketika imbalan hasil yang diberikan oleh Bank Indonesia kepada Bank Islam dari SBIS adalah bonus yang prosen-tase besarnya tidak sama dengan imbalan hasil dari BI rate dari SBI yang dilakukan oleh bank konvensional. Hal ini juga me-nimbulkan polemik tersendiri bagi Bank Is-lam ketika pihak Bank Islam sebenarnya menuntut besarnya bonus yang diberikan oleh Bank Indonesia atas SBIS juga sama dengan $B I$ rate yang berlaku untuk bank konvensional atas SBI. Hal ini sesuai dengan informasi yang disampaikan oleh informan sebagai berikut:
"...ketika kita menyimpan dana kita ke SBIS, return yang kita dapat sedikit karena itu bonus, tapi sebenarnya ha-rusnya Bank Indonesia harusnya bisa memberikan return yang sama dengan SBI, kan hampir sama SBI dengan SBIS cuma SBI 
untuk bank konven-sional dan SBIS untuk Bank Islam. Sekarang coba dihitung selisihnya, misalkan diprosentasikan imbalan dari SBI bisa mencapai 7- $13 \%$ sedangkan bonus yang diberikan atas SBIS cuma sekitar 2-4\%, makanya kenapa bank konvensional itu bisa mengadakan gelegar hadiah besar-besaran buat nasabahnya, salah satu sumber dananya ya diperoleh dari selisih antara bu-nga deposito dengan bunga SBI".

Berdasarkan pernyataan tersebut Bank Islam harusnya dapat menjalankan salah satu fungsinya secara komperatif untuk menyediakan jasa keuangan bagi perbankan lain yang membutuhkan likuiditas melalui sarana PUAS yang tersedia bukan untuk mencari posisi aman dengan tingkat resiko yang lebih kecil dan imbal hasil (bonus) yang lebih pasti dengan lebih mem-ilih SBIS dari pada PUAS dalam menyalur-kan overlikuid-nya yang memiliki tingkat risiko yang lebih tinggi dan tingkat imbal hasil yang belum pasti karena mengguna-kan sistem bagi hasil.

Selanjutnya, selain melalui SBIS bank Islam tersebut juga melakukan penge-lolaan likuiditas melalui PUAS juga, mes-kipun prosentasenya lebih kecil daripada SBIS dan PUAS ini jarang digunakan yang disebabkan terlalu tingginya resiko yang harus ditanggung ketika Bank Islam terse-but harus ke PUAS. Ketika Bank Islam tersebut menggunakan PUAS untuk penge-lolaan likuidiasnya, maka sebenarnya ada instrumen yang digunakan oleh Bank Islam tersebut yaitu sertifikat Investasi Mudha-rabah Antarbank (IMA), akan tetapi selama proses penelitian yang dilakukan, sebagian besar pegawai dari Bank Islam tersebut tidak mengenal dengan istilah IMA, hanya beberapa pegawai dengan posisi tertentu saja yang memang mengetahui yaitu mana-ger operasional dan accounting officer dari Bank Islam tersebut.
Keanggotaan dari PUAS ini terdiri dari bank konvensional maupun Bank Islam, akan tetapi ada pembedaan pemberlakuan keanggotaan PUAS ini antara anggota Bank Islam dengan bank konvensional di mana bank konvensional hanya bertindak sebagai penyedia dana saja (pena-nam dana), sedangkan Bank Islam kedua-duanya (penanam dan pengelola dana), hal ini dimaksudkan untuk menghindari pe-nggunaan dana yang tidak sesuai dengan prinsip-prinsip Islam yang dijalankan. Hal ini sesuai dengan informasi yang disampai-kan oleh salah satu informan bahwa:

\section{"Semua bank baik itu konvensional maupun Bank Islam boleh masuk da- lam pasar uang, cuma kalau di pasar uang ini bank konvensional hanya se- bagai investor saja, karena menghin- dari ketidak-Islama-nya dalam peng- gunaan dananya".}

Hal tersebut sesuai dengan peraturan PBI No 2/8/PBI/2000 tentang peserta PUAS ini yang terdiri dari Bank Islam maupun bank konvensional. Di mana bank Islam dapat melakukan penanaman dana dan atau pengelolaan dana, sedangkan bank konvensional hanya dapat melakukan pena-naman dana. Jika dilihat secara kelem-bagaan ekonomi, transaksi ini tidak adil karena hanya salah satu jenis bank saja yang boleh melakukan pengelolaan dana (Bank Islam) sedangkan jenis yang lainnya hanya sebagai penanam dana (bank konvensional). Hal ini jika dilihat dari sisi ke-Islam-an transaksi yang dilakukan, wa-jar sekali jika ada perlakuan yang berbeda antara anggota PUAS yang menggunakan prinsip Islam dengan yang menggunakan prinsip konvensional karena untuk meng-hindari ketidak-Islam-an dalam penge-lolaan dana yang dilakukan oleh perbankan konvensional atas dana yang diperoleh dari transaksi di PUAS.

Sebenarnya dalam pengelolaan likuiditas setiap bank Islam memiliki cara, ka- 
rakteristik dan kebijakan masing-masing yang disesuaikan dengan kebutuhan dari bank Islam tersebut serta dari kinerjanya. Di mana Bank Islam tersebut sudah melakukan perkiraan perhitungan tersendiri ketika bank Islam tersebut mau menggunakan pilihan mekanisme menggunakan SBIS atau melalui mekanisme PUAS. Hal ini bia-sanya berhubungan dengan image dari perbankan Islam itu sendiri terkait dengan per-forma kinerja keuangan dari perbankan Islam.

Perbankan Islam mengutamakan penggunaan fasilitas SBIS dilatarbelakangi oleh, (a) kesulitan perbankan Islam untuk menyalurkan pembiayaan ke masyarakat dengan tepat karena terkait dengan moral hazard masyarakat pada penggunaan pembiayaan yang disalurkan (b) kondisi antar bank yang mengalami overlikuid sehingga tidak ada bank yang membutuhkan dana likuiditas, dan (c) sebagai bentuk minimalisir resiko terhadap investasi dana bank dan harapan untuk mendapatkan tingkat "return" yang lebih pasti. Kenyataanya ketika pengelolaan likuiditas pada perbakan Islam dilakukan melalui SBIS masih menimbulkan suatu permasalahan tersendiri yaitu pertama, selama ini perbankan Islam masih mempermasalahkan tingkat return yang diberikan oleh Bank Indonesia atas dana yang dititipkan pada SBIS yang berbeda dengan return yang diberikan atas SBI oleh perbankan konvensional. Kedua jika mayoritas perbankan Islam melakukan penempatan dana pada SBIS akan menyebabkan kelesuan pada sektor riil, karena pada prinsipnya dana yang dititipkan di Bank Indonesia (BI) hanya "diam" dan tidak tersalurkan ke sektor riil. Hal ini tidak sesuai dengan prinsip ekonomi Islam di ma-na setiap perputaran dana harus diiringi de-ngan pergerakan sektor riil.

Selanjutnya, (2) pengelolaan likuiditas melalui transaksi PUAS dengan menggunakan sertifikat IMA tetap digunakan meskipun menjadi pilihan kedua. Hal ini disebabkan prosedur yang rumit dalam mekanisme penggelolaan likuiditas melalui transaksi PUAS. Meskipun demikian tran-saksi PUAS dengan sertifikat IMA (Inves-tasi Mudharabah Antarbank) lebih sering digunakan untuk mengatasi kebutuhan jangka pendek pada perbankan Islam. Pa-dahal semestinya untuk melakukan pembi-ayaan, sesuai dengan akad Mudharabah yang digunakan pada transaksi PUAS ter-sebut. Selain itu, fasilitas jangka waktu overnight juga digunakan pada mekanisme jual beli sertifikat IMA, sehingga perlu di-tinjau ulang lagi karena secara logika dana tersebut belum dapat disalurkan pada usaha-usaha produktif dalam waktu semalam. Sementara akad yang digunakan dalam transaksi ini adalah akad Mudharabah yang secara prinsip keuntungan akan diperoleh dari hasil investasi sektor riil.

Sebenarnya pengelolaan likuiditas dengan menggunakan SBIS maupun melalui transaksi PUAS belum mampu menjawab problem riil yang dihadapi perbankan Islam dalam mengalokasikan idle money yang diakibatkan oleh adanya overlikud. Hal ini terjadi karena pembiayaan oleh perbankan Islam belum sepenuhnya sesuai dengan prinsip-prinsip Islam. Kondisi ini disebabkan perbankan Islam Indonesia masih dalam proses transisi dari sistem konvensional ke sistem Islam, sehingga dual banking system sering rancu dalam penggunaannya.

Selanjutnya, hasil kajian dari penelitian ini menunjukan bahwa perilaku perbankan Islam di dalam mekanisme dual banking system masih dilatarbelakangi oleh motif persaingan dengan perbankan kon-vensional. Hal ini dilatarbelakangi oleh pertama, sifat dari perbankan itu sendiri bahwa pada hakikatnya merupakan busi-ness entity baik perbankan Islam maupun perbankan konvensional dimana tujuan dari usaha perbankan tersebut adalah mencari keuntungan, sehingga ada perilaku trade off yang dialami oleh perbankan Islam dalam menjalankan usaha perbankan untuk men-jadi bisnis yang 
menguntungkan sesuai de-ngan tujuan prinsip Islam.

\section{KESIMPULAN, IMPLIKASI, SA- RAN, DAN BATASAN}

Berdasarkan pada hasil kajian dalam pembahasan, dapat disimpulkan sebagai be-rikut ini:

Pengelolaan likuiditas pada perbankan Islam terdapat tiga pilihan yang dapat digunakan yaitu Sertifikat Bank Indonesia Indonesia Islam (SBBIS), Pasar Uang Antar Bank (PUAS) melalui instrumen Sertifikat Investasi Mudharabah Antar Bank (SIMA) dan Fasilitas Jangka Pendek Bank Indonesia. Dari ketiga pilihan tersebut, perbankan Islam cenderung memilih menggunakan SBIS dan transaksi PUAS. Sedangkan fasilitas jangka pendek Bank Indonesia hanya digunakan sebagai alternative terakhir. Fasilitas jangka pendek Bank Indonesia tidak menarik karena penggunaan fasilitas ini akan mempengaruhi penilaian kinerja perbankan Islam oleh Bank Indonesia.

Perilaku perbankan Islam dalam mekanisme dual banking system menghadapi permasalahan tradeoff antara keberadaan perbankan Islam itu sebagai business entity dan prinsip perbankan itu Islam itu sendiri. Hal ini terjadi karena perbankan Islam di Indonesia juga dihadapkan oleh persaingan dengan perbankan konvensional yang sudah lebih dahulu berkembang. Sehingga tidak heran jika perilaku perbakan Islam hampir sama dengan perilaku bank konvensional dalam melakukan pengelolaan likuiditas.

Sistem perbankan Indonesia yang menganut dual banking system belum secara jelas berjalan sesuai dengan masing-masing sistem yang dianut. Karena selama ini secara spesifik belum ada kebijakan moneter yang dapat digunakan secara khusus oleh perbankan Islam dalam pengelolaan likuiditas.

Adapun rekomendasi dari penulis berdasarkan pada kesimpulan yang telah disampaikan adalah sebagai berikut:
Bank Indonesia perlu melakukan peninjauan kembali atas penggunaan sertifikat SBIS oleh bank Islam dalam pengelolaan overlikuiditasnya sehingga tidak menyebabkan kelesuan dalam sektor riil.

Perlu adanya pengembangan instrument yang ada di PUAS oleh Bank Indonesia selaku otoritas moneter tanpa mengindahkan aspek keIslamannya karena melihat betapa pentingnya peranan pasar uang dalam pengelolan likuiditasnya untuk bank Islam maupun untuk perekonomian secara umum.

Diperlukan sebuah kajian yang lebih mendalam lagi tentang seperti apa instrument yang cocok untuk memenuhi kebutuhan jangka pendek yang ada dalam transaski PUAS lebih utamanya pada akad yang digunakan untuk memenuhi kebutuhan jangka pendek dalam transaski di PUAS.

\section{DAFTAR PUSTAKA}

Abdul-rahman, Aisyah., Radziah Abdul Latif., Ruhaini Muda., Muhammad Azmi Abdullah. (2014). Failure and Potential of Profit-Loss Sharing Contracts: A Prespective of New Institutional Economic (NIE) Theory. Pacific-Basin Finance Journal 28, pp: 135

Anto. (2010). Manajemen Likuiditas Perbankan Islam. Akses: 25 Desember 2013.http://ekisonline.com/index2.php?opti on=com_content \&do_pdf=1\&id=194

Antonio, Muhammad Syafi'i. (2001). Bank Islam dari Teori ke Praktik. Jakarta: Gema Insani.

Aris, Nooraslinda Abdul., Rohana Othman., Rafidah Mohd Azli., Mardiyyah Sahri., Dz-uljastri Abdul Razak., Zaharudin Abdul Rahman. (2013). Islamic 
Banking Products: Regulations, Issues and Challenges. The Journal of Applied Bussiness Research, Vol.29, No. 4, pp:1145-1156

Ascarya. (2010). Alur Transmisi dan Efektifitas Kebijakan Moneter Ganda di Indonesia. PPSK Working Paper Series No: WP/10/03. Bank Indonesia.

Beck, Thorsten., Asli Demirguc-Kunt., Ourda Merrouche. (2013). Islamic vs Conventional banking: Bussiness model, efficiency and stability. Journal banking and Finance 37, pp: 433-447

Bank Indonesia, Peraturan Bank Indonesia Nomor 2/8/PBI/2000 Tentang Pasar Uang Antarbank Berdasarkan Prinsip Islam

Bungin, Burhan. (2007). Analisis Data Penelitian Kualitatif. Jakarta: PT. Raja Grafindo Persada

Cetak Biru Pengembangan Perbankan Islam di Indonesia. (2002) Bank Indonesia Chapra, M. Umer. (2000). Sistem Moneter Islam, Jakarta : Gema Insani Press

Chong, Beng Soon., Ming-Hua Liu. (2009). Islamic Banking: Interest-free or Interest Based?. Pacific-Basin Finance Journal, Vol. 17, pp: 125-144

Faruq, Moazzam., Sajjad Zaheer. (2015). Are Islamic Bank More Resilient during Financial Panic?. IMF Working Paper, WP/15/41, pp: 1-28

Hachicha, Najib., Amine Ben Amer. (2015). Does Islamic Bank Financing Contribute to Economic Growth? The Malaysian Case. International Journal of Islamic and Middle Eastern Finance and Management, Vol. 8, Issue. 3, pp: 349-368

Haz, Hamzah. (2006). Shariah Banking System: An Instrument to Accelerate Nation Empowerment. Seminar
Procedding Isla-mic Finance Architecture: risk Manage-ment and Financial Stability No 46, pp: 33-36

Ismal, Rifki. Model of Islamic Monetary Operation For Liquidity Management In Islamic Banking Case of Indonesia 20002009. Gadjah Mada International Journal Business: 2010.

, (2010). Islamic Banking

Characteristics, Economic Condition and Liquidity Risk Problem (Indonesia Case : 2001 - 2007), akses : 03 Desember 2013. http://www.docstoc.com/docs/9464086/isla mic-banking-and-liquidity-risk-problem

Kabir, Md Nurul., Andrew Worthington., RakeshGupta. (2015). Comparative Credit Risk in Islamic and Conventional Bank. Pacific-Basin Finance Journal.Vol. xxx, pp: $\mathrm{xxx}-\mathrm{Xxx}$ (article in prees)

Karim, Adiwarman. (2003). Bank Islam Analisa Fiqih dan Keuangan, Jakarta: The International Institute of Islamic Thought. Mishkin, Frederic S. (2004). The Economist of Money, Banking and Financial Markets. Seventh Edition. Columbia University. United States Amerika

Khan, H., and Bashar, O.K.M.R. (2008). Islamic Finance: Growth and Prospects in Singapore, U21Global Working Paper Series, no.001/2008

Khan, M. Mansoor., M. Ishaq Bhatti. (2008). Islamic Banking and Finance: on its way to globalization. Managerial Finance, Vol. 34, No. 10, pp: 708-725

Khan, Mohsin S., Abbas Mirakhor. (1990). Islamic Banking: Experiences in The Islamic Republic of Iran and in Pakistan. Economic Development and Cultural Change, Vol. 38, No. 2, pp: 353-375

Khan, Mohsin S., Abbas Mirakhor. (1990). Islamic Banking: Experiences in The Isla- 
mic Republic of Iran and in Pakistan. Economic Development and Cultural Change, Vol. 38, No. 2, pp: 353-375

Nasir, Mohd. (2009). Do the Treasury Activities Fuction Well ini Shari'ah-Compliant Financial Market?: Internasional Business Research, Vol. 2, (No.3). ww-

w.ccsenet.org/journal.html. Diakses pada 14 Oktober 2016

Muhammad. (2014). Manajemen Dana Bank Islam. Jakarta: PT Rajagrafindo Persada

Siddiqi, M. Najatullah. .Pendekatan Islam Terhadap Ekonomi. Diakses melalui https://elpinadelaz07.wordpress.com/2014/ 05/03/pemikiran-ekonomi-islam-kontemporer-muhammad-nejatullah-siddiqi/ diakses pada tanggal 1 Agustus 2016

Sudararajan, V., Luca Erico. (2002). Islamic Financial Institutions and Products in the Global Financial System: Key Issues in Risk Management and Challenges Ahead. IMF Working Paper, WP/02/192, pp: $1-27$

Tarek S. Zaher \& M. Kabir Hassan. (2001). A Comparative Literature Survey of Islamic Finance and Banking. Financial Markets, Institutions \& Intruments, V. 10, No. 4 Nov-ember 2001, University Salomon New York

Yahya, Muchlis, \& Edy Yusuf Agung Gun-anto. (2011). Teori bagi hasil (profit and loss sharing) dan perbankan syarah dalam ekonomi Islam. Jurnal Dinamika Ekonomi Pembangunan. Juli. Volume 1 nomor 1 